\title{
Sprawl and the Resilience of Humans and Nature: an Introduction to the Special Feature
}

\author{
Craig R. Allen ${ }^{1}$
}

Human-driven change in land use and land cover is an accelerating global phenomenon with farreaching implications for food production, forest and water resources, the climate, and biogeochemical cycles (Foley et al. 2005). It affects the amount and configuration of habitat available for animals ranging from soil nematodes to elephants. It affects the provision of ecological goods and services for human beings. It affects the processes and function of ecosystems.

"Sprawl", as it has been termed, is exurban human land use change with a footprint exceeding the minimum required for the activity developed. It is that disproportionately large footprint that defines a certain type of growth as sprawl. It leads to large expanses of human-built environment with a global biota of tramp species. Sprawl is an extremely recent phenomenon in geological terms, but even in human-historical terms it is a recent phenomenon. The spread of sprawling growth is often viewed as rapid, but it is an additive phenomenon increasing with each generation. Each generation is likely to recognize only those changes that have occurred within their lifetimes, a shifting baseline (Pauley 1995) that may make social change and recognition of the problem more difficult. However, in the United States and elsewhere, sprawl has been occurring and recognized for several generations, as epitomized by the writing of John Steinbeck (1995: 194-195):

"This four-lane concrete highway slashed with speeding cars I remember as a narrow, twisting mountain road where the wood teams moved, drawn by steady mules ... This was a little little town, a general store under a tree and a blacksmith shop and a bench in front on which to sit and listen to the clang of hammer on anvil. Now little houses, each one like the next, particularly since they try to be different, spread for a mile in all directions. That was a woody hill with live oaks dark green against the parched grass where the coyotes sang on moonlit nights. The top is shaved off and a television relay station lunges at the sky and feeds a nervous picture to thousands of tiny houses clustered like aphids beside the roads."

Steinbeck (1959:195-196) continues:

"I remember Salinas, the town of my birth, when it proudly announced four thousand citizens. Now it is eighty thousand and leaping pell mell on in a mathematical progression - a hundred thousand in three years and perhaps two hundred thousand in ten, with no end in sight. Even those people who joy in numbers and are impressed with bigness are beginning to worry, gradually becoming aware that there must be a saturation point and the progress may be a progression toward strangulation. And no solution has been found. You can't forbid people to be born - at least not yet."

The current population of Salinas proper is approximately 150,000 , and of Monterey County, California, approximately 410,000.

Sprawl affects the resilience of complex socialecological systems in a myriad of ways, some of which are touched upon in the papers featured in this special issue of Ecology and Society. By acting as a barrier to ecological processes and to the dispersal of animals and plants, sprawl, as with other human transformations of landcover, may reduce the population viability of many wild species and the adaptive and evolutionary potential of animals and systems. Sprawl alters ecological structures and functions and thus affects the provision of ecological goods and services. Ultimately, sprawl may reduce the resilience of linked socialecological systems. Sprawl-type growth may well serve to sever and undermine the linkages between 
social (urban) systems and ecosystems. It doubtlessly increases the need for extrinsic inputs into urban systems and decreases the geographic area of productive ecosystems available to support cities, estimated to be 565-1130 times greater than the area of the cities supported (Folke et al. 1997). Additionally, there are negative and welldocumented impacts of sprawl on human health (Frumkin et al. 2004). Understanding, quantifying, predicting, and communicating the social and ecological changes following urbanization are critical for sustainability of our ecological, social, and economic systems.

The papers in this feature all address issues associated with what has become known as "urban sprawl." The papers in this feature can be categorized into three groups, although there is overlap: (1) those focused on forecasting and predicting the effects of sprawling growth, (2) those focused on understanding the effects on natural systems and native species, and (3) those focused on understanding impacts on human well-being and health.

Understanding where and how urban growth will occur is clearly important, and often difficult. To predict land transition probabilities and simulate urban growth through 2030 for the area around Charleston, South Carolina, USA, Allen and Lu (2003) develop methods based on a logistic framework that also incorporate rule-based suitability modules and focus groups. Such models may help decision-makers anticipate and mitigate the potential negative impacts of sprawl. Wear et al. (2004) use modeling of urban and economic growth to assess the effects of such growth on the area of interior forest in the southeastern United States. The models of Wear et al. (2004) may be useful for assessing conservation priorities focused on maintaining core areas necessary for the persistence of species with large area requirements and the maintenance of natural disturbance regimes. Ricketts and Imhoff (2003) explicitly tackle the problem of assigning priorities to conservation decisions. They use animal and plant distributions and urban and agricultural land-use data to locate areas in which high levels of biological diversity coincide with human dominance of land use and suggest that these areas should receive priority in the conservation decision-making process. Bengston and Youn (2006) offer an in-depth analysis of one of the policy tools that have been used in an attempt to control urban land use and sprawl: greenbelts.
Their examination of the impacts of the implementation of a highly restrictive greenbelt in Seoul, South Korea, reveals that it has provided a mix of both benefits and costs. The costs are primarily economic because of longer commute times and higher housing costs, but the quality of life is also affected. Benefits include economic savings attributable to efficiency in the provision of services and many advantages for quality of life. Bengston and Youn (2006) argue that, despite the controversy associated with the greenbelt and current challenges to its maintenance, Seoul gains much in terms of heritage and ecological services from the greenbelt.

In addition to understanding where urban growth will occur, it is important to understand the biological impacts of sprawl. Three papers in this feature address that question. Blair (2004) presents an investigation of the impacts of urbanization on avian species. For individual birds, nest predation actually decreased with urbanization, although those results, with artificial nests, were not reflected in nesting success. For species, sprawl affected patterns of extinction and invasion, and the richness and diversity of communities peaked at moderate levels of urbanization. Blair (2004) suggests that, at the level of continents, extinction of endemics and invasion of ubiquitous tramp species leads to faunal homogenization. Forys and Allen (2005) examine the relationship between ant species and urbanization in the Lower Keys of Florida. They document that richness of both common and rare native ant species is positively correlated with nonnative species. Areas that supported many species of native ants also supported a diverse non-native ant fauna, and the species distribution was highly nested. Christie and Hochuli (2005) demonstrate that trees in urban fragments of natural habitat have higher levels of leaf damage than both edge and interior sites in continuous areas of natural habitat. The authors suggest that fragmented remnants in urban areas are high-stress environments characterized by biotic shifts that lead to increases in folivorous insects because higher trophic groups such as parasatoids and birds are more likely to be lost from urban remnants.

The remaining papers in this feature focus on the sociological and human health aspects of sprawling growth. Jensen et al. (2004) examine the effects of sprawl on human quality of life by assessing relationships between urban forest resources and socioeconomic conditions. The authors document 
positive correlations between urban leaf area, human population density, and median income and housing value. Because leaf area, human population density, and their interaction statistically account for the observed variance in income and housing value, the authors suggest that they may be used as quality-of-life metrics. Haller (2005) describes the decline and restructuring of the steel industry in the Pittsburg, Pennsylvania, USA, region, and its consequences. These include the decline of working-class communities because of a transition to low inputs of labor and raw material, an increase of persistent joblessness and poverty, and the growth of an urban underclass. Haller draws parallels to the structural changes in other industries affected by politics and economics, such as the new international division of labor and globalization of production.

In the area of human health, Vo et al. (2004) and Kleppel et al. (2004) focus on water quality and toxic contaminants. Vo et al. (2004) build a statistical model that incorporates toxicity data, ultraviolet extinction coefficients, historical sediment chemistry, and bathymetric data into a spatial model of sedimentary areas of an estuary to predict which ones are most vulnerable to toxicity from photoinduced polycyclic aromatic hydrocarbons. These hydrocarbons result from vehicle emissions, and the contamination of water bodies increases with increasing area in impervious surfaces, that is, increasing urbanization. Kleppel et al. (2004) determined that two key attributes of urban systems, the amount of vegetated buffer between the urban landscape and receiving waters and the amount of land in urban use, strongly influence water quality and ecosystem function in the wetlands they studied. Thus, urban typology influences the environmental impacts resulting from urban growth. Conroy et al. (2003) focus on land-use and landscape changes in the southeastern United States, an area of rapid population and urban growth. The authors characterize the problems, tradeoffs and decisionmaking processes associated with uncontrolled growth and focus on three dominant and recurring themes: scale effects, resilience, and uncertainty. Andersson (2006) explores a framework for understanding and building sustainable cities. He argues that cities have always been dependent on ecosystems for critical goods and services, and that increasing urbanization further disconnects people from their ecological support systems. To increase support for the conservation of ecological systems and, therefore, sustainable ecological-social systems, Andersson (2006) suggests that cities should provide opportunities for human interaction with the natural world, and that resilience, especially spatial aspects of resilience theory, provide an appropriate framework for designing the urban areas that are sustainable.

The papers in this feature do not represent a comprehensive assessment of urban sprawl. There are several recent books (e.g., Squires 2002, Frumkin et al. 2004) and review articles (e.g., McKinney 2002) that do that. Rather, the papers herein represent a sampling of some recent research focusing on the impacts of sprawl. The rate of urban and exurban growth in the United States and many other parts of the world is continuing to accelerate, and it is important to understand and attempt to mitigate the negative impacts of such growth on both people and nature.

Responses to this article can be read online at:

http://www.ecologyandsociety.org/voll1/iss 1/art36/responses/

\section{Acknowledgments:}

The Nebraska Cooperative Fish and Wildlife Unit is jointly supported by a cooperative agreement between the United States Geological Survey, the Nebraska Game and Parks Commission, the University of Nebraska-Lincoln, the United States Fish and Wildlife Service, and the Wildlife Management Institute.

\section{LITERATURE CITED}

Allen, J., and K. Lu. 2003. Modeling and prediction of future urban growth in the Charleston region of South Carolina: a GIS-based integrated approach. Ecology and Society 8(2):2. [online] URL: http://www.ecologyandsociety.org/vol8/iss2/ $\underline{\operatorname{art} 2 / /}$.

Andersson, E. 2006. Urban landscapes and sustainable cities. Ecology and Society 11(1): 34. [online] URL: http://www.ecologyandsociety.org/vol11/ iss $1 / \operatorname{art} 34 /$.

Bengston, D., and Y. C. Youn. 2006. Urban containment policies and the protection of natural 
areas: the case of Seoul's greenbelt. Ecology and Society 11(1):3. [online] URL: http://www.ecology andsociety.org/vol11/iss1/art3/.

Blair, R. 2004. The effects of urban sprawl on birds at multiple levels of biological organization. Ecology and Society 9(5):2. [online] URL: http://w ww.ecologyandsociety.org/vol9/iss5/art2/.

Christie, F. J., and D. F. Hochuli. 2005. Elevated levels of herbivory in urban landscapes: are declines in tree health more than an edge effect? Ecology and Society 10(1):10. [online] URL: http://www.ecolog yandsociety.org/vol10/iss1/art10/.

Conroy, M. J., C. R. Allen, J. T. Peterson, L. J. Pritchard, and C. T. Moore. 2003. Landscape change in the southern Piedmont: challenges, solutions, and uncertainty across scales. Ecology and Society 8(2):3. [online] URL: http://www.ecolo gyandsociety.org/vol8/iss2/art3/.

Foley, J. A., R. DeFries, G. P. Asner, C. Barford, G. Bonan, S. R. Carpenter, F. S. Chapin, M. T. Coe, G. C. Daily, H. K. Gibbs, J. H. Helkowski, T. Holloway, E. A. Howard, C. J. Kucharik, C. Monfreda, J. A. Patz, I. C. Prentice, N. Ramankutty, and P. K. Snyder. 2005. Global consequences of land use. Science 309:570-574.

Folke, C., A. Jansson, J. Larsson, and R. Costanza. 1997. Ecosystem appropriation by cities. Ambio 26:167-172.

Forys, E., and C. R. Allen. 2005. The impacts of sprawl on biodiversity: the ant fauna of the lower Florida Keys. Ecology and Society 10(1):25. [online] URL: http://www.ecologyandsociety.org/vol10/ iss $1 /$ art 25/.

Frumkin, H., L. Frank, and R. Jackson. 2004. Urban sprawl and public health: designing, planning, and building for healthy communities. Island Press, Washington, D.C., USA.

Haller, W. 2005. Industrial restructuring and urban change in the Pittsburgh region: developmental, ecological, and socioeconomic trade-offs. Ecology and Society 10(1):13. [online] URL: http://www.ec ologyandsociety.org/vol10/iss1/art13/.

Jensen, R., J. Gatrell, J. Boulton, and B. Harper. 2004. Using Remote Sensing and Geographic Information Systems to Study Urban Quality of Life and Urban Forest Amenities. Ecology and Society 9(5):5. [online] URL: http://www.ecologyandsociety. org/vol9/iss5/art5/.

Kleppel, G.S., S. A. Madewell, and S. E. Hazzard. 2004. Responses of emergent marsh wetlands in upstate New York to variations in urban typology. Ecology and Society 9(5):1. [online] URL: http://w ww.ecologyandsociety.org/vol9/iss 5/art1/.

McKinney, M. L. 2002. Urbanization, biodiversity, and conservation. BioScience 52:883-890.

Pauley, D. 1995. Anecdotes and the shifting baseline syndrome of fisheries. Trends in Ecology and Evolution 10:430.

Ricketts, T., and M. Imhoff. 2003. Biodiversity, urban areas, and agriculture: locating priority ecoregions for conservation. Ecology and Society 8 (2):1. [online] URL: http://www.ecologyandsociety. org/vol8/iss2/art1/.

Squires, G. D. 2002. Urban sprawl: causes, consequences, and policy responses. Urban Institute Press, Washington, D.C., USA.

Steinbeck, J. 1962. Travels with Charley. Viking Penguin, New York, New York, USA.

Vo, M., D. Porter, G. Chandler, H. Kelsey, S. Walker, and B. E. Jones. 2004. Assessing photoinduced toxicity of polycyclic aromatic hydrocarbons in an urbanized estuary. Ecology and Society 9(5):3. [online] URL: http://www.ecologya ndsociety.org/vo19/iss5/art3/.

Wear, D., J. Pye, and K. Riitters. 2004. Defining conservation priorities using fragmentation forecasts. Ecology and Society 9(5):4. [online] URL: http://w ww.ecologyandsociety.org/vol9/iss5/art4/. 